\title{
EVALUASI KINERJA FISIK SISTEM SUBAK YANG BERORIENTASI AGROEKOWISATA MENGGUNAKAN PENDEKATAN LOGIKA FUZZY
}

\author{
SUMIYATI, ${ }^{1}$ LILIK SUTIARSO,${ }^{2}$ WAYAN WINDIA, ${ }^{3}$ DAN PUTU SUDIRA ${ }^{4}$ \\ ${ }^{1}$ Jurusan Teknik Pertanian, Fakultas Teknologi Pertanian, Universitas Udayana, Bali. \\ ${ }^{2}$ Jurusan Teknik Pertanian, Fakultas Teknologi Pertanian, Universitas Gadjah Mada, Yogyakarta. \\ 3,4 Jurusan Agribisnis, Fakultas Pertanian, Universitas Udayana, Bali. \\ E-mail: adendanino@yahoo.co.id
}

\begin{abstract}
ABSTRAK
Seiring dengan perkembangan pariwisata di Bali, salah satu fenomena yang terjadi adalah bahwa konversi lahan ke lahan non-pertanian, menyebabkan saluran irigasi tidak dapat berfungsi lagi. Selain itu, kebutuhan air akan meningkat tidak hanya untuk irigasi, tetapi juga untuk sektor lainnya dari irigasi. Kondisi ini dapat mengganggu kinerja dari sistem subak. Salah satu strategi untuk meningkatkan sistem subak adalah untuk mengembangkan agroekowisata berdasarkan sistem subak. Analisis kinerja sistem subak fisik dilakukan dengan menggunakan pendekatan logika fuzzy untuk mengukur kondisi ketidakjelasan. Karena masalah yang terkait dengan kinerja sistem irigasi subak sering kabur dan tidak dapat diklasifikasikan dengan pasti. Hasil penelitian ini adalah (i) nilai-nilai sistem indikator kinerja irigasi subak, kondisi dan fungsi sarana irigasi subak, kondisi dan fungsi fasilitas subak, dan fasilitas agroekowisata, (ii) mengetahui kinerja fisik sistem irigasi subak di Bali dengan agroekowisata berorientasi. Tahapan penelitian ini adalah mengumpulkan dan analisis data meliputi: (i) RWS (Relative Water Supply), (ii) RIS (Relative Irrigation Supply), (iii) Ia (Index Area), (iv) analisis kondisi dan fungsi jaringan irigasi subak, (v) kondisi dan fungsi fasilitas subak, (vi) fasilitas agroekowisata, dan (vii) kinerja fisik dari sistem subak menggunakan pendekatan logika fuzzy. Tingkat pemanfaatan air di Subak Anggabaya dan Subak Lodtunduh dalam satu tahun itu baik. Subak Anggabaya dan Subak Lodtunduh memiliki pasokan air irigasi yang cukup dengan nilai-nilai RIS dalam satu tahun > 1. Berdasarkan Indeks Area (IA), bisa dilihat bahwa daerah irigasi di Subak Anggabaya dan Subak Lodtunduh sesuai dengan rencana. Kinerja fisik Anggabaya subak sistem dan Subak Lodtunduh sistem adalah dalam kriteria menengah. Simulasi hasil bahwa pengembangan agroekowisata pada sistem subak dapat meningkatkan kinerja fisik dari sistem subak.
\end{abstract}

Kata kunci: kinerja irigasi, subak, agroecotourism, logika fuzzy

\begin{abstract}
Along with the development of the tourism in Bali, one of the phenomena occurs was that the land conversion to the non-agricultural land, causing the canal irrigation was not able to function again. In addition, water demand will be increased not only for irrigation, but also for other sectors out of irrigation. This condition can interfere the performance of the subak system. One strategy to improve subak system is to develop agroecotourism based on subak system. Analysis of physical performance subak system done using fuzzy logic approach to quantify the condition of vagueness. Because of the problems associated with subak irrigation system performance are often vague and can not be classified with certainty. The results of this study are (i) the values of subak irrigation system performance indicators, the condition and the function of subak irrigation facilities, the condition and the function of subak facilities, and the agroecotourism facilities; (ii) find out the physical performance of subak irrigation systems in Bali with agroecotourism oriented. The stages of this research were collecting and analyting the data include: (i) RWS (Relative Water Supply), (ii) RIS (Relative Irrigation Supply), (iii) Ia (Index Area), (iv) analysis of the condition and function of subak irrigation networks, (v) the condition and the function of subak facilities, (vi) the agroecotourism facilities, and (vii) physical performance of subak system using fuzzy logic approach. The utilization rate of water on Subak Anggabaya and Subak Lodtunduh in one year was good. Subak Anggabaya and Subak Lodtunduh have sufficient irrigation water supply with RIS values in one year $>1$. Based on Area Index (Ia), it could be seen that the irrigated area in Subak Anggabaya and Subak Lodtunduh in accordance with the plan. The physical performance of Anggabaya subak system and Lodtunduh Subak system was in the middle criteria. The simulation results that development of agroecotourism on subak system could improve the physical performance of subak system.
\end{abstract}

Keywords: irrigation performance, subak, agroecotourism, fuzzy logic 


\section{PENDAHULUAN}

Dalam Peraturan Daerah Provinsi Bali No. 02/ PD/DPRD/1972 dinyatakan bahwa subak adalah suatu masyarakat hukum adat yang memiliki karakteristik sosio-agraris-religius, yang merupakan perkumpulan petani yang mengelola air irigasi di lahan sawah. Salah satu keistimewaan dari sistem subak adalah bahwa pengelolaan subak berazaskan pada konsep Tri Hita Karana (THK). Dengan memakai azas Tri Hita Karana (THK), subak dapat mengelola irigasi dan juga lahan pertanian secara harmonis sehingga sistem subak dapat bertahan secara berkelanjutan.

Pulau Bali masih menjadi tujuan wisata utama di Indonesia. Namun seiring dengan berkembangnya pariwisata, salah satu fenomena yang terjadi adalah alih fungsi lahan ke arah non pertanian, yang berakibat merugikan bagi petani subak karena saluran irigasi tidak dapat difungsikan lagi karena ditutup atau ditimbun. Di samping itu, kebutuhan air meningkat bukan saja untuk irigasi, tetapi juga untuk sektor-sektor di luar irigasi seperti hotel, villa, restoran, dan beberapa wisata alam misalnya rafting dan sebagainya, serta PDAM. Subak sebagai organisasi yang berlandaskan sosio kultural tidak mampu untuk melawan intervensi yang datang dari pihak eksternal tersebut, sehingga akan dapat mengganggu kinerja sistem subak.

Salah satu strategi untuk meningkatkan kemampuan subak adalah dengan mengembangkan agroekowisata berbasis subak. Pengembangan agroekowisata pada sistem subak akan mampu meningkatkan kinerja irigasi serta kondisi dan fungsi jaringan irigasi serta fasilitas subak. Oleh karena itu dilakukan penelitian, salah satunya adalah tentang "Evaluasi Kinerja Fisik Sistem Subak Yang Berorientasi Agroekowisata Menggunakan Pendekatan Logika Fuzzy".

Dalam menilai kinerja fisik sistem subak yang berorientasi agroekowisata, hal-hal yang perlu dipertimbangkan adalah faktor kinerja irigasi subak, kondisi dan fungsi fasilitas subak serta pada subak berorientasi agroekowisata, kinerja fisik juga dipengaruhi oleh fasilitas agroekowisata. Hal tersebut karena sebagai sebuah sistem irigasi subak memiliki jaringan irigasi atau fasilitas irigasi, dan dalam konteks subak di Bali terdapat pula fasilitas subak yang tidak bisa terlepas dari kehidupan subak karena subak adalah lembaga yang bercorak sosioreligius. Oleh karena itu, baik buruknya suatu subak juga dapat dilihat dari baik buruknya fasilitas subak.
Tujuan dari penelitian ini adalah untuk (i) menentukan nilai-nilai indikator kinerja sistem irigasi subak, kondisi dan fungsi fasilitas irigasi serta fasilitas subak; (ii) mengetahui bagaimana kinerja fisik sistem irigasi subak di Bali yang berorientasi agroekowisata. Indikator kinerja irigasi subak yang digunakan dalam penelitian ini meliputi RWS (Relative Water Supply), RIS (Relative Irrigation Supply), dan Ia (Index Area) (Sanyoto, 2002). Analisis matematika dengan pendekatan logika fuzzy diperlukan untuk mengkuantifikasi parameter kinerja fisik yang tidak seluruhnya bersifat kuantitatif. Logika fuzzy memiliki toleransi terhadap data-data yang tidak tepat dan mampu memodelkan fungsi-fungsi non-linier yang sangat kompleks.

\section{METODE}

Penelitian dilaksanakan pada Subak Lodtunduh yang berada di Desa Singakerta, Kecamatan Ubud, Kabupaten Gianyar, Bali, dengan luas 25,67 ha dan jumlah anggota: 62 orang, serta Subak Anggabaya yang berada di Kelurahan Penatih, Kecamatan Denpasar Timur, Kota Denpasar, Bali, dengan luas 39,37 ha dan jumlah anggota: 92 orang. Kedua subak sampel merupakan subak yang berpotensi untuk dikembangkan menjadi kawasan agroekowisata.

Data-data tentang agroekowisata diperoleh dengan melakukan survei pada tempat-tempat yang mengembangkan sistem sejenis, diantaranya Banjar Beng Kaja, Tabanan; Agrowisata Kertalangu pada Subak Padanggalak, Sanur; dan Banjar Kiadan, Pelaga, Badung.

Adapun tahapan dalam penelitian ini adalah pengumpulan data dan analisis data yang meliputi RWS (Relative Water Supply, RIS (Relative Irrigation Supply, Ia (Index Area), dan analisis kinerja sistem subak menggunakan pendekatan logika fuzzy.

\section{Pengumpulan Data}

Penelitian dilaksanakan dengan melakukan pengumpulan data di lapangan baik data primer maupun sekunder. Pengumpulan data dan informasi primer dilakukan dengan menggunakan metode survei dan pengukuran di lapang.

Adapun data-data yang diperlukan dalam penelitian ini adalah seri data klimatologi yang diolah menggunakan software CROPWAT untuk mendapatkan nilai-nilai kebutuhan air tanaman dan kebutuhan air irigasi, seri data debit, data luas tanam rencana dan aktual, data kondisi dan fungsi jaringan irigasi, serta data kondisi dan fungsi fasilitas subak. 


\section{Analisis data}

Analisis data secara empiris dilakukan terhadap data yang bersifat kuantitatif. Analisis data dilakukan dengan melakukan perhitungan terhadap beberapa indikator kinerja sistem irigasi subak, meliputi RWS (Relative Water Supply, RIS (Relative Irrigation Supply, Ia (Index Area), dan analisis kinerja sistem subak menggunakan pendekatan logika fuzzy.

\section{RWS (Relative Water Supply)}

RWS menggambarkan apakah suplai air irigasi mencukupi atau tidak (Behailu, dkk. 2005). Nilai RWS menghubungkan jumlah total suplai air (termasuk curah hujan) dengan kebutuhan air tanaman total. Hal tersebut merupakan suatu indikator untuk menilai potensi pemanfaatan air total yang diterima oleh suatu daerah irigasi. Suatu daerah irigasi yang mempunyai nilai $\mathrm{RWS}=1$, berarti pada daerah irigasi tersebut tidak terjadi kelebihan air atau kekurangan air. Dengan kata lain, jumlah air yang dibutuhkan sama dengan jumlah air yang tersedia (Behailu, dkk. 2005). Persamaan untuk mendapatkan nilai RWS disajikan pada persamaan 1 .

$\mathrm{RWS}=\frac{\mathrm{TWS}}{\mathrm{CWR}}$

\section{RIS (Relative Irrigation Supply)}

RIS menunjukkan apakah kebutuhan air irigasi dapat dipenuhi atau tidak (Behailu, dkk. 2005). Persamaan untuk mendapatkan nilai RIS disajikan pada persamaan 2 .

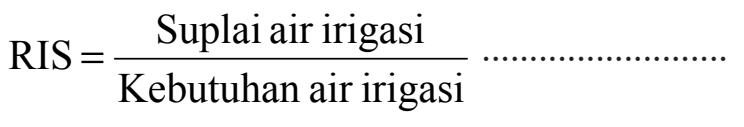

\section{Ia (Index Area)}

Ia (Index Area) menunjukkan rasio antara luas aktual yang dilayani terhadap luas layanan yang direncanakan. Persamaan untuk mendapatkan nilai Ia disajikan pada persamaan 3 .

$\mathrm{Ia}=\frac{\mathrm{A}_{\text {act. }}}{\mathrm{A}_{\text {renc. }}}$

\section{Analisis kinerja sistem subak menggunakan pendekatan logika fuzzy}

Data yang diperlukan untuk analisis kondisi dan fungsi jaringan irigasi adalah kondisi dan fungsi saluran (telabah), bangunan bagi (tembuku) dan drainase (pengutangan). Kondisi dan fungsi fasilitas subak ditunjukkan oleh kondisi dan fungsi dari pura subak, balai subak, dan jalan subak. Data fasilitas agroekowisata meliputi data tentang jalur tracking, data fasilitas penunjang agroekowisata seperti akomodasi, penjualan souvenir, resto, dan toilet. Data kondisi dan fungsi jaringan irigasi subak diolah dengan menggunakan pendekatan logika fuzzy, untuk mengkuantifikasikan kondisi kekaburan.

Pendekatan logika fuzzy telah digunakan pada beberapa penelitian di antaranya untuk menentukan faktor yang paling dominan berpengaruh pada keberlanjutan sistem irigasi (Arif, 2000), mengelompokkan dan mengurutkan kinerja DI (Daerah Irigasi) pasca-PIK (Penyerahan Irigasi Kecil) (Murtiningrum, dan Dadang, 2005), serta penilaian kinerja jaringan irigasi tersier (Murtiningrum dan Dadang, 2007).

Analisis penilaian kinerja fisik sistem subak dilakukan dengan menggunakan pendekatan logika fuzzy (fuzzy logic) untuk mengkuatifikasi kondisi kekaburan. Karena persoalan-persoalan yang berkaitan dengan kinerja sistem irigasi subak seringkali bersifat kabur dan tidak dapat digolongkan dengan pasti, maka pendekatan logika fuzzy secara relatif akan dapat dipakai untuk menempatkan persoalan-persoalan tersebut berdasarkan pada kepentingan menurut kondisi pengamatan kondisi jaringan irigasi, fasilitas subak dan agroekowisata. Teori kekaburan menyediakan teknik sistematis untuk mengkuatifikasi tolok ukur kinerja sistem irigasi yang kabur karena batas-batas nilainya tidak tegas.

Diagram causal pada penilaian kinerja fisik sistem subak berorientasi agroekowisata disajikan pada Gambar 1. Analisis data dilakukan menggunakan program fuzzy bawaan software Matlab. Langkah pertama penggunaan program fuzzy tersebut adalah membuka FIS editor, kemudian merancang berapa input dan output yang akan digunakan dalam analisa yang dilakukan sesuai dengan diagram causal pada Gambar 3. Langkah selanjutnya adalah membuat range value yang yang dikehendaki dan penamaan pada masing-masing membership. Tahapan berikutnya adalah menyusun aturan (rules) sesuai dengan kondisi sistem. Selanjutnya dapat diinput nilai-nilai input dari rules tersebut dan dapat diketahui nilai outputnya. 


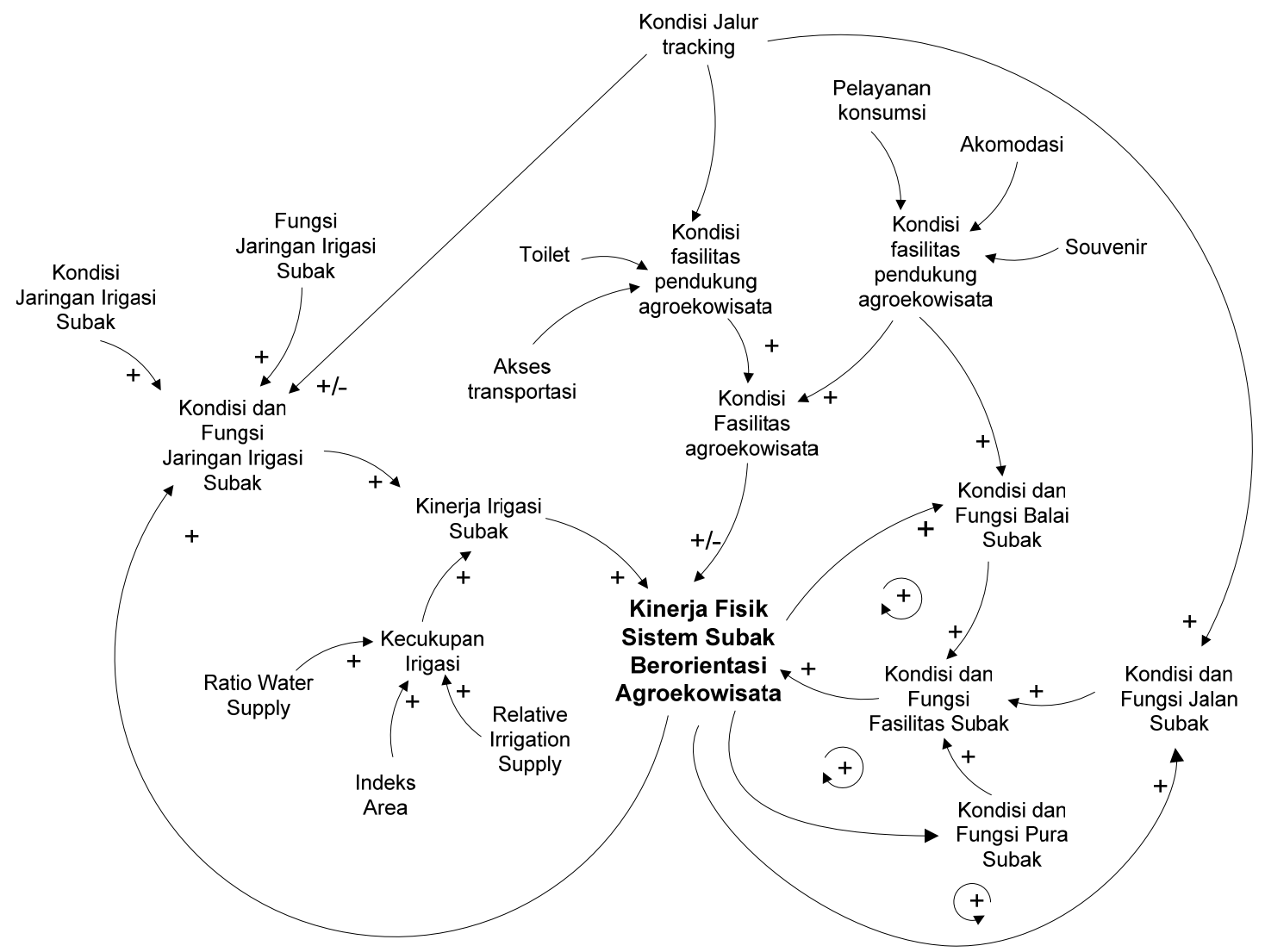

Gambar 1. Diagram causal pada penilaian kinerja fisik sistem subak berorientasi agroekowisata

\section{HASIL DAN PEMBAHASAN}

\section{RWS (Relative Water Supply)}

Menurut Bastiaanssen dalam Sanyoto (2002) bahwa interval RWS yang dapat diterima adalah 0.9-1.4. Nilai RWS Subak Anggabaya dan Subak Lodtunduh disajikan pada Tabel 1.

Tabel 1. Nilai RWS subak sampel

\begin{tabular}{lcc}
\hline \multicolumn{1}{c}{ Bulan } & $\begin{array}{c}\text { RWS Subak } \\
\text { Anggabaya }\end{array}$ & $\begin{array}{c}\text { RWS Subak } \\
\text { Lodtunduh }\end{array}$ \\
\hline Januari & 3.4 & 1.3 \\
Februari & 1.4 & 2.3 \\
Maret & 0.9 & 2.8 \\
April & 0.7 & 0.8 \\
Mei & 1.0 & 0.9 \\
Juni & 0.7 & 1.5 \\
Juli & 0.6 & 0.9 \\
Agustus & 0.6 & 0.6 \\
September & 1.7 & 0.7 \\
Oktober & 0.7 & 1.3 \\
November & 0.8 & 2.5 \\
Desember & 0.9 & 1.0 \\
\hline Rata-rata & 1.1 & 1.4 \\
\hline
\end{tabular}

Berdasarkan Tabel 1. dapat diketahui bahwa tingkat pemanfaatan air pada Subak Anggabaya $($ RWS $=1.1)$ dan Subak Lodtunduh $($ RWS $=1.4)$ secara umum dalam satu tahun adalah baik.

Nilai RWS lebih besar dari pada 1, berarti jumlah pasokan air berlebih. Pada bulan Januari pada Subak Anggabaya serta bulan Februari dan Maret pada Subak Lodtunduh menunjukkan nilai RWS yang relatif tinggi. Hal ini disebabkan karena pada bulan-bulan tersebut merupakan musim hujan dan tanaman pada fase panen sehingga kebutuhan air tanaman relatif kecil.

Kelebihan air pada sistem subak dikelola dengan sistem suplesi dan drainase yang terpisah dalam satu komplek pemilikan sawah, yang terkenal dengan sebutan one inlet \& one outlet system. Pada sistem ini terdapat pintu pengambilan/pintu sadap (tembuku pengalapan) pada setiap blok/kompleks individual sawah petani. Teknologi yang ada dalam konsep ini diantaranya adalah bahwa petani dapat mengadakan diversifikasi tanaman tanpa ada konflik dalam pengelolaan air irigasi (meski pelaksanaan diversifikasi dilaksanakan pada musim hujan). Di 
samping itu juga terdapat saluran drainase/saluran pembuangan pada setiap blok/kompleks individual sawah petani (Windia, 2006).

\section{RIS (Relative irrigation supply)}

Nilai RIS Subak Anggabaya dan Subak Lodtunduh disajikan pada Tabel 2. Nilai RIS pada Subak Anggabaya terendah adalah 0.28 dan pada Subak Lodtunduh nilai RIS terendah adalah 0.41. Kondisi dengan nilai RIS yang relatif kecil pada Subak Anggabaya dan Subak Lodtunduh tersebut terjadi pada periode-periode pengolahan tanah. Namun hal ini dapat di atasi dengan adanya sistem pinjam air antara anggota subak (Sutawan, 2008). Hal tersebut mungkin dilakukan karena pengolahan tanah dilakukan tidak secara serempak dalam hari yang sama, namun bergiliran antar petani anggota subak.

Suplai air irigasi pada Subak Lodtunduh dan Subak Anggabaya cenderung berlebih pada sebagian besar periode yang disuplai oleh curah hujan atau pada periode pemanenan bero sesaat setelah panen sekitar 1-2 minggu, biasanya digunakan untuk menggembalakan itik atau bebek. Kondisi ini lebih banyak terjadi di Subak Lodtunduh dibandingkan dengan Subak Anggabaya. Hal tersebut dikarenakan Subak Lodtunduh lokasinya berada di hulu, sedangkan Subak Anggabaya berada di hilir. Hal tersebut sesuai dengan neraca air pada Subak Anggabaya dan Subak Lodtunduh, yang dapat dilihat pada Gambar 2. dan Gambar 3.

Tabel 2. Nilai RIS subak sampel

\begin{tabular}{lrr}
\hline Bulan & RIS Subak Anggabaya & RIS Subak Lodtunduh \\
\hline Jan I & $\sim$ & $\sim$ \\
Jan II & $\sim$ & $\sim$ \\
Jan III & $\sim$ & $\sim$ \\
Feb I & 0.29 & $\sim$ \\
Feb II & 0.95 & $\sim$ \\
Feb III & $\sim$ & $\sim$ \\
Mar I & $\sim$ & $\sim$ \\
Mar II & 120.69 & $\sim$ \\
Mar III & 5.00 & $\sim$ \\
Apr I & 5.74 & $\sim$ \\
Apr II & 4.30 & 3.99 \\
Apr III & 3.46 & 3.20 \\
May I & 3.39 & 5.23 \\
May II & 11.77 & 11.36 \\
May III & $\sim$ & 5.71 \\
Jun I & 0.20 & 8.94 \\
Jun II & 1.75 & $\sim$ \\
Jun III & 1.76 & $\sim$
\end{tabular}

\begin{tabular}{lcc}
\hline Bulan & RIS Subak Anggabaya & RIS Subak Lodtunduh \\
\hline Jul I & 1.79 & 39.36 \\
Jul II & 1.68 & 0.44 \\
Jul III & 1.31 & 0.46 \\
Aug I & 1.21 & 1.83 \\
Aug II & 1.15 & 1.55 \\
Aug III & 1.08 & 1.47 \\
Sep I & 1.94 & 1.87 \\
Sep II & $\sim$ & 2.16 \\
Sep III & $\sim$ & 3.19 \\
Oct I & 0.28 & 8.11 \\
Oct II & 0.72 & $\sim$ \\
Oct III & 2.74 & 6.39 \\
Nov I & 4.47 & $\sim$ \\
Nov II & 5.26 & $\sim$ \\
Nov III & 6.01 & 0.43 \\
Dec I & 9.44 & 0.41 \\
Dec II & 23.42 & $\sim$ \\
Dec III & 11.66 & $\sim$ \\
\hline Keterangan & &
\end{tabular}

Keterangan:

: kebutuhan air irigasi adalah 0 liter/detik (kebutuhan air tanaman sudah dipenuhi oleh curah hujan efektif).

I, II, III : periode pemberian air sepuluh harian.

Berdasarkan Gambar 2. dan Gambar 3. dapat dilihat bahwa sebagian besar kebutuhan air irigasi (KAI) dapat dipenuhi oleh debit tersedia (Q), namun terjadi peningkatan kebutuhan air yang tinggi adalah pada saat pengolahan tanah yaitu di Subak Anggabaya pada periode Feb I, Feb II, Jun I, Okt I dan Okt II, sedangkan di Subak Lodtunduh pada periode Jul II, Jul III, Nov III dan Des I. Meningkatnya kebutuhan air hingga jauh melebihi debit tersedia pada periode pengolahan tanah tersebut dapat di atasi dengan adanya sistem pinjam air antara anggota subak. Sutawan (2008) menyebutkan bahwa pinjammeminjam air antara anggota subak terutama oleh anggota yang sawahnya mendapat air dari saluran kuarter yang sama atau saling berdekatan, sudah biasa diterapkan di kalangan subak. Jangka waktu peminjaman tergantung pada kebutuhan dan persetujuan pihak yang dipinjami, misalnya beberapa jam saja, atau sampai 1-2 hari.

\section{Ia (Index Area)}

Debit air yang selalu tersedia sepanjang tahun memungkinkan pola tanam dengan intensitas tinggi sehingga lahan tidak pernah bero hingga satu musim tanam dan lahan dapat diairi sesuai luas yang direncanakan. Ia (Index Area) pada Subak Anggabaya dan Subak Lodtunduh dapat dilihat pada Tabel 3. 


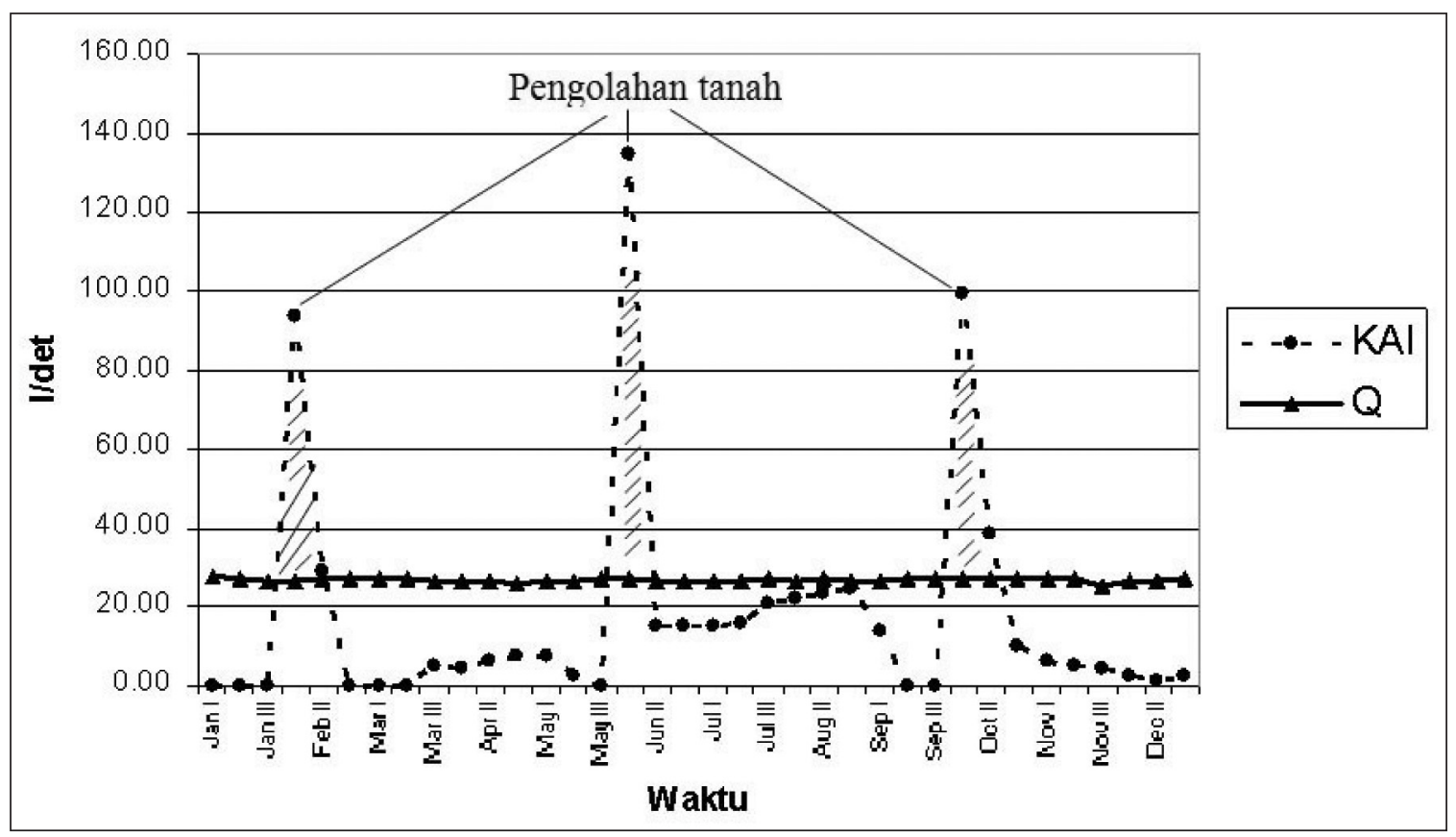

Gambar 2. Neraca air Subak Anggabaya

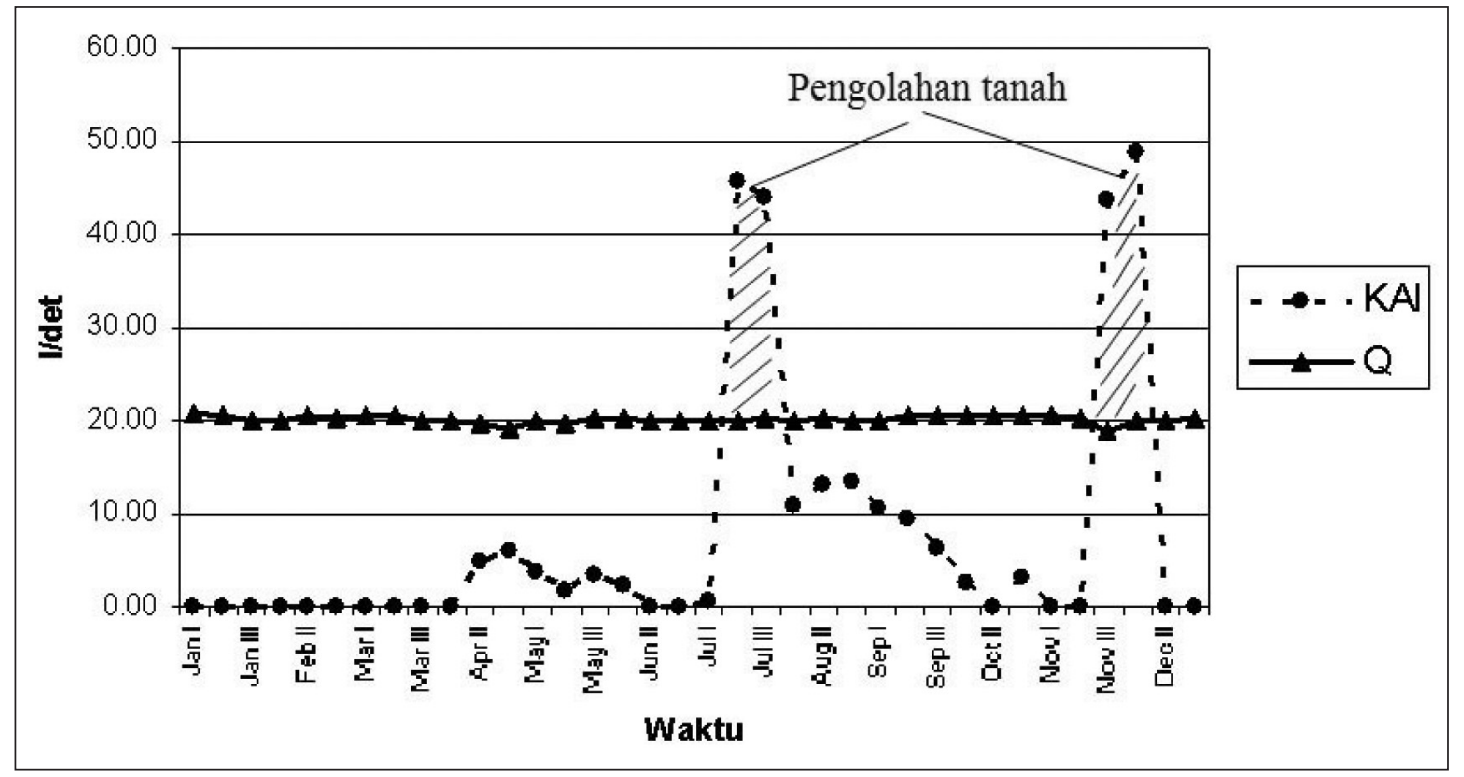

Gambar 3. Neraca air Subak Lodtunduh

Tabel 3. Nilai Ia (Index Area) pada subak sampel

\begin{tabular}{lc}
\hline \multicolumn{1}{c}{ Nama Subak } & Indeks Luas (Ia) \\
\hline Subak Anggabaya & 1 \\
Subak Lodtunduh & 1 \\
\hline
\end{tabular}

Berdasarkan Ia (Index Area) pada Tabel 3 digambarkan bahwa luasan lahan yang terairi pada Subak Anggabaya dan Subak Lodtunduh sudah sesuai dengan yang direncanakan yaitu 39,37 ha dan 25,67 ha. Luas lahan aktual yang diairi dapat sesuai dengan luas lahan rencana karena ketersediaan air yang mencukupi. Subak Anggabaya dan Subak Lodtunduh menerapkan pola tanam tiga kali setahun tanpa ada hambatan yang berarti terutama dari ketersediaan air.

\section{Kinerja fisik sistem irigasi subak}

Kinerja fisik sistem subak meliputi kinerja irigasi serta kondisi dan fungsi fasilitas subak. Kinerja irigasi subak ditunjukkan dengan kondisi dan fungsi 

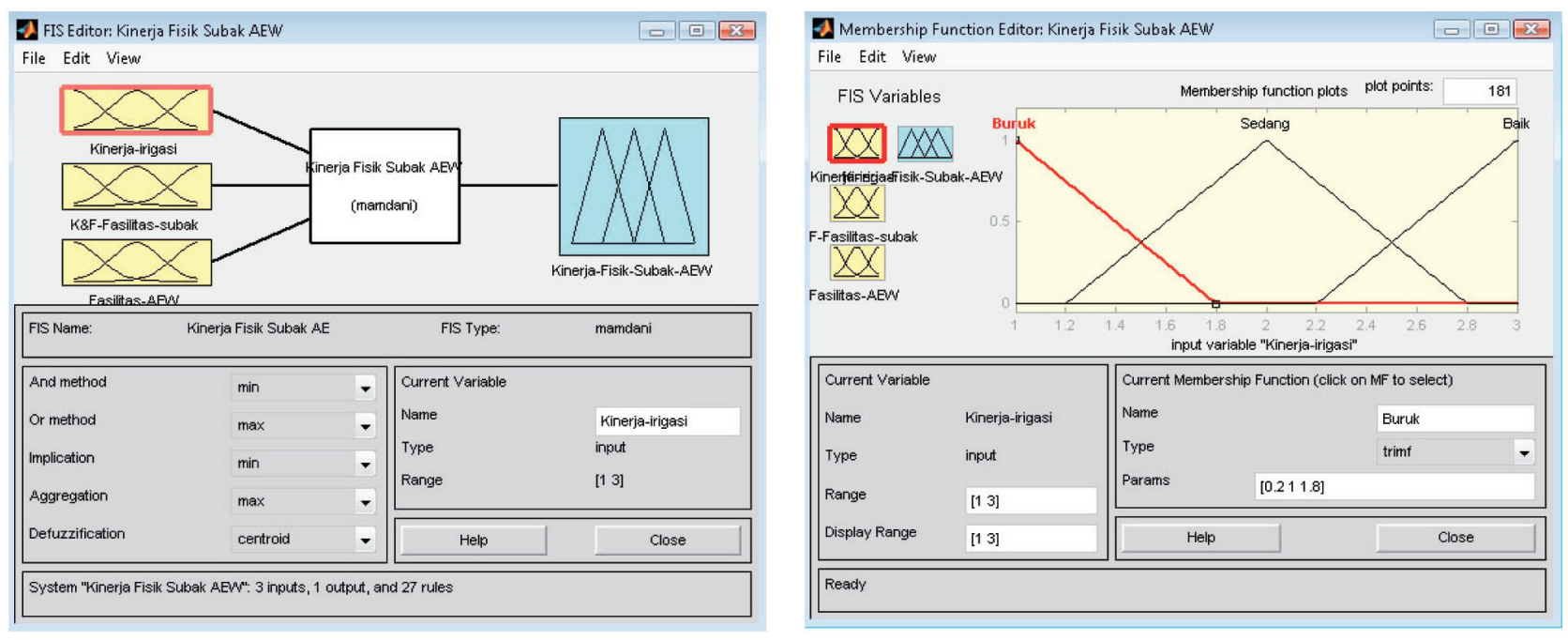

Gambar 4. Beberapa tahapan analisis menggunakan logika fuzzy untuk mengevaluasi kinerja fisik sistem subak

saluran, bangunan bagi dan drainase serta tingkat kecukupan air irigasi dengan indikator RWS dan Ia. Sedangkan kondisi dan fungsi fasilitas subak ditunjukkan oleh kondisi dan fungsi dari pura subak, balai subak, dan jalan subak. Gambaran beberapa tahapan analisis menggunakan logika fuzzy untuk mengevaluasi kinerja fisik sistem subak dapat dilihat pada Gambar 4 dan hasil analisis data menggunakan pendekatan logika fuzzy sesuai dengan diagram causal pada Gambar 1 disajikan pada Tabel 4.

Berdasarkan Tabel 4 dapat diketahui bahwa kinerja teknis sistem irigasi Subak Anggabaya berada pada kriteria sedang agak baik dan Subak Lodtunduh berada pada kriteria sedang. Kinerja irigasi Subak Anggabaya pada umumnya baik, hanya saluran irigasi yang terganggu oleh rumput walaupun masih dapat berfungsi dengan baik. Kondisi fasilitas Subak Anggabaya pada umumnya agak baik (antara sedang dan baik) namun dapat berfungsi dengan baik.

Pada Subak Lodtunduh, kinerja irigasi pada umumnya baik, hanya saluran irigasi yang terganggu oleh rumput dan saluran drainase sebagian kecil mengalami kerusakan, namun masih dapat berfungsi dengan baik. Kondisi fasilitas Subak Lodtunduh pada umumnya agak baik (antara sedang dan baik) namun dapat berfungsi dengan baik. Hanya jalan subak yang merupakan pematang sawah petani anggota subak, beberapa tempat mengalami longsor dan licin sehingga agak sulit dilalui.

Pengembangan agroekowisata pada sistem subak, dapat meningkatkan kinerja fisik sistem subak seperti disajikan pada Tabel 4. Kinerja fisik Subak Anggabaya sebagai daerah pertanian diperoleh fuzzy value 2,02 dan kinerja fisik Subak Anggabaya berorientasi agroekowisata pada kondisi eksisting 2,00. Sedangkan kinerja fisik Subak Anggabaya jika agroekowisata dikembangkan secara ideal diperoleh fuzzy value meningkat menjadi 2,21. Kinerja fisik Subak Lodtunduh sebagai daerah pertanian diperoleh fuzzy value 2,00 dan kinerja fisik Subak Lodtunduh berorientasi agroekowisata pada kondisi eksisting 2,00. Sedangkan kinerja fisik Subak Lodtunduh jika agroekowisata dikembangkan secara ideal diperoleh fuzzy value meningkat menjadi 2,23.

Agroekowisata yang dikembangkan pada sistem subak disini adalah suatu usaha wisata yang dikelola subak dengan objek wisata wilayah pertanian subak serta manajemen pengelolaan memperhatikan prinsip-prinsip ekowisata. Berkaitan dengan hal tersebut, fasilitas agroekowisata dianggap baik apabila memenuhi prinsip-prinsip ekowisata. Diantaranya adalah fasilitas jogging track memanfaatkan pematang sawah alami namun tertata, akomodasi di rumah-rumah penduduk petani anggota subak, menu makanan lokal setempat dan penyediaan makanan dilakukan oleh anggota subak serta tempat penyajian dapat dilakukan di rumah penduduk petani anggota subak atau di balai subak. Pengadaan souvenir oleh penduduk petani anggota subak.

Dengan pengembangan agroekowisata tersebut, diharapkan kedepannya dapat meningkatkan kinerja fisik sistem subak secara berkesinambungan. Fasilitas irigasi dan fasilitas subak juga merupakan objek atraksi agroekowisata, sehingga dengan berkembangnya agroekowisata kondisi dan fungsinya akan diadakan perbaikan-perbaikan untuk dapat memenuhi keindahan dan kenyamanan wisatawan. 
Tabel 4. Kinerja fisik sistem subak berorientasi agroekowisata

\begin{tabular}{|c|c|c|c|}
\hline \multirow{2}{*}{ Parameter } & \multicolumn{2}{|c|}{ Fuzzy value } & \multirow{2}{*}{ Kriteria } \\
\hline & Subak Anggabaya & Subak Lodtunduh & \\
\hline Kondisi dan Fungsi Jaringan Irigasi & 2,53 & 2,47 & $\begin{array}{l}\text { 1: buruk } \\
\text { 2: sedang } \\
\text { 3: baik }\end{array}$ \\
\hline Kecukupan Air Irigasi & 3,00 & 3,00 & $\begin{array}{l}\text { 1: kekurangan } \\
\text { 2: cukup } \\
\text { 3: berlebih }\end{array}$ \\
\hline Kinerja Irigasi Subak & 2,21 & 2,15 & $\begin{array}{l}\text { 1: buruk } \\
\text { 2: sedang } \\
3: \text { baik }\end{array}$ \\
\hline Kondisi dan Fungsi Fasilitas Subak & 2,25 & 2,00 & $\begin{array}{l}\text { 1: buruk } \\
\text { 2: sedang } \\
\text { 3: baik }\end{array}$ \\
\hline $\begin{array}{l}\text { Kinerja Fisik Sistem Subak } \\
\text { (pertanian) }\end{array}$ & 2,02 & 2,00 & $\begin{array}{l}\text { 1: buruk } \\
\text { 2: sedang } \\
\text { 3: baik }\end{array}$ \\
\hline Fasilitas Agroekowisata (eksisting) & 1,45 & 1,45 & $\begin{array}{l}\text { 1: buruk } \\
\text { 2: sedang } \\
\text { 3: baik }\end{array}$ \\
\hline $\begin{array}{l}\text { Kinerja Fisik Sistem Subak Berorientasi } \\
\text { Agroekowisata (eksisting) }\end{array}$ & 2,00 & 2,00 & $\begin{array}{l}\text { 1: buruk } \\
\text { 2: sedang } \\
\text { 3: baik }\end{array}$ \\
\hline $\begin{array}{l}\text { Fasilitas Agroekowisata } \\
\text { (dikembangkan) }\end{array}$ & 2,53 & 1,55 & $\begin{array}{l}\text { 1: buruk } \\
\text { 2: sedang } \\
\text { 3: baik }\end{array}$ \\
\hline $\begin{array}{l}\text { Kinerja Fisik Sistem Subak Berorientasi } \\
\text { Agroekowisata (dikembangkan) }\end{array}$ & 2,21 & 2,23 & $\begin{array}{l}\text { 1: buruk } \\
\text { 2: sedang } \\
\text { 3: baik }\end{array}$ \\
\hline
\end{tabular}

\section{SIMPULAN}

Kinerja fisik sistem subak dipengaruhi oleh kinerja irigasi subak dan kondisi serta fungsi fasilitas subak yaitu pura subak, balai subak, dan jalan subak. Pada subak berorientasi agroekowisata, kinerja fisik juga dipengaruhi oleh fasilitas agroekowisata. Tingkat pemanfaatan air pada Subak Anggabaya dan Subak Lodtunduh berdasarkan nilai RWS dalam satu tahun adalah baik. Berdasarkan nilai RIS pada Subak Anggabaya dan Subak Lodtunduh diketahui bahwa nilai RIS yang relatif kecil terjadi pada periodeperiode pengolahan tanah. Namun hal ini dapat di atasi dengan adanya sistem pinjam air antara anggota subak. Suplai air irigasi pada Subak Lodtunduh dan Subak Anggabaya cenderung berlebih pada sebagian besar periode yang disuplai oleh curah hujan atau pada periode pemanenan bero sesaat setelah panen sekitar 1-2 minggu. Berdasarkan Ia dapat diketahui bahwa luasan lahan yang terairi pada Subak Anggabaya dan Subak Lodtunduh sudah sesuai dengan yang direncanakan yaitu 39,37 ha dan 25,67 ha. Kinerja fisik Subak Anggabaya sebagai daerah pertanian diperoleh fuzzy value 2,02 dan kinerja fisik Subak Anggabaya berorientasi agroekowisata pada kondisi eksisting 2,00. Sedangkan kinerja fisik Subak Anggabaya jika agroekowisata dikembangkan secara ideal diperoleh fuzzy value yang meningkat menjadi
2,21. Kinerja fisik Subak Lodtunduh sebagai daerah pertanian diperoleh fuzzy value 2,00 dan kinerja fisik Subak Lodtunduh berorientasi agroekowisata pada kondisi eksisting 2,00. Sedangkan kinerja fisik Subak Lodtunduh jika agroekowisata dikembangkan secara ideal diperoleh fuzzy value yang meningkat menjadi 2,23 .

\section{DAFTAR PUSTAKA}

Arif, S.S., 2000. Keberlanjutan Sistem Irigasi dalam Pembangunan Jangka Panjang Kedua (Studi Kasus di Pulau Jawa dan Bali). Laporan Pelaksanaan RUT VI.1 Tahun 1999/2000. P3PK UGM. Yogyakarta.

Behailu, M., Abdulkadir, M., Mezgebu, A., and Yasin, M., 2005. Performance Evaluation of Community Based Irrigation Management in the Tekeze Basin. A collaborative project between Mekelle University, ILRI and EARO Funded through the IWMIComprehensive Assessment of Water for Agricultural Program. http://www.iwmi.cgiar.org/assessment/files/ word/Workshops/ILRI-March/Presentations/Atinkut. $p d f$. (2 Maret 2011).

Dick, R., 1995. Timeliness of Irrigation. Performance Indicators and Impact on Agricultural Production in the Sone Irrigation System, Bihar. Irrigation and Drainage Systems 9: 371-387. Kluwer Academic Publisher. Netherlands. 
Murtiningrum, D.A.A. dan Dadang, R., 2005. Penilaian Kinerja Jaringan Irigasi Tersier Menggunakan Teori Himpunan Kekaburan. Prosiding Seminar Nasional Teknik Pertanian. Yogyakarta.

Murtiningrum, W.W. dan Rahajeng, M., 2007. Penentuan Kinerja Pengelolaan Irigasi Daerah Irigasi Bondoyudo, Jawa Timur. Prosiding Seminar Nasional Teknik Pertanian. Yogyakarta.

Sanyoto, F.S., 2002. Penggunaan Indikator Kinerja Irigasi Untuk Mengetahui Tingkat Pemanfaatan Air di
Daerah Irigasi Kecil (Studi Kasus Daerah Irigasi Jelog Kab. Kulonprogo). Jurusan Teknik Pertanian, Fakultas Teknologi Pertanian, UGM. Yogyakarta. (Skripsi, tidak dipublikasikan).

Sutawan, N., 2008. Organisasi dan Manajemen Subak di Bali. Penerbit Pustaka Bali Post, Denpasar.

Windia, W., 2006. Transformasi Sistem Irigasi Subak yang Berlandaskan Konsep Tri Hita Karana. Penerbit Pustaka Bali Post, Denpasar. 